\title{
ESSENCE AND SIGNIFICANCE OF THE CHRISTIAN FAITH IN THE MODERN WORLD
}

\author{
Ivan Valkov \\ Kiev Theological Seminary, BIC GCB, Kiev, Ukraine \\ i.i.valkov@abv.bg
}

\begin{abstract}
The author offers a discursive analysis of the New Testament faith, based on the biblical definition of it (Heb. 11) and the realization in life of the Old Testament patriarch Abraham, a model of faith in the three monotheistic religions. The author's choice fell to Abraham because of the similarity in God's guidance to him in the Old Testament and to the images in the New Testament. This leads to theological conclusions about what the biblically based Christian faith should be today. In the theological-ethical analysis of the successive stages in the stepwise development of the faith, visualized in the author's diagram, the correct definition, meaning and influence of each stage in the real life of the modern Christian stand out. The theoretical aspect of the research uses methods of systematic theology, biblical hermeneutics, egzegetics, as well as scientific research on the concept of "faith" (VI. Sveshnikov, K. Barth, Al. Men, VI. Solovov, D. Kirov etc.). The practical aspect of the study is based on the spiritual experience of Abraham, the historical experience of the Church, as well as the personal experience of the author - theologian and clinical psychologist. This text aims to inspire Christians to overcome daily trials by boldly climbing the steps of faith, which also elevates Abraham to the true glory God has given him. God's promise is that trials will never exceed the power of the one who has ben tested.
\end{abstract}

Keywords: Faith; Christianity

\section{СЪЩНОСТ И ЗНАЧЕНИЕ НА ХРИСТИЯНСКАТА ВЯРА В СЪВРЕМЕННИЯ СВЯТ}

\author{
Иван Въ^КОВ \\ Киевская Богословская Семинария БНЦ ЕХБ, Киев, Украйна
}

\begin{abstract}
Резюме: Авторьт преллага Аискурсивен анализ на новозаветната вяра, основан на библейското определение за нея (Евр. 11 гл.) и реализацията в живота на старозаветния патриарх Авраам, образец на вярата в трите монотеистични религии. Изборьт на автора пална на Авраам поради сходството в Божието водителство към него в Стария завет и към образите в Новия завет. Оттук се правят богословски изводи за това каква слеАва $А$ б бъАе

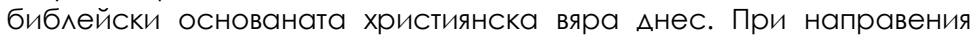
богословско-етичен анализ на послелователните етапи в
\end{abstract}


стьпаловиАното развитие на вярата, визуализирани в авторска миаграма, се открояват правилното дефиниране, значение и влияние на всеки етап в реалния живот на съвременния християнин. Теоретичния аспект на изследването ползва метоли на систематичното богословие, библейската херменевтика, екзегетиката, както и научни изследвания на понятието "вяра" (ВА. Свещников, К. Барт, А^. Мен, ВА. Соловьов, А. Киров и Ар..). Практическият аспект на изслеАването се основава върху Ауховния опит на Авраам, историческия опит на Цьрквата, както и мичния опит на автора - богослов и кАиничен психолог. Този текст цели $А$ व вАьхнови християните $А$ преоАоляват ежеАневните изпитания чрез Арьзновено изкачване по стьпалата на вярата, което издига и Авраам Ао истинската слава, Аалена му от Бога. А Божието обещание е, че изпитанията никога няма да налвишат силата на изпитвания.

КАючови Ауми: вяра, християнство

В по-общ смисъл вярата може да се разглежла като културно и исторически обусловена Ауховно-нравствена категория. Homo sapiens като еАинствен неин субект от зората на историята се е интересувал и е изучава^ същността на обекта на вярата, която е приема^ или избирал за своя. Историята на християнската вяра свиАетелства за наличието на богат опит в това отношение. Трябва $А$ признаем обаче, че през посленните десетилетия в християнска Европа и Америка сме свилетели на сериозна криза в прилагането на новозаветната вяра, породена от мипсата на зарава основа за същата тази вяра и погрешно виждане за модела на нейното развитие. Правилното дефиниране на понятието вяра е особено важно в практическото богословие и ежедневието на християните в Аигиталния свят. В опит Аа запьлни тази Аипса настоящия текст, като част от зальлбочено авторско изслеАване по темата за вярата [Вълков, Ив.] (Valkov, 2008) цели фрокусиран анализ на понятието от глеАна точка на богословието и психологията.

Основни източници, които ползваме в изследването, освен Библията (Bible, 2006), са анализите на понятието вяра на В^. Свещников, К. Барт, А^. Мен, Вл. Соловьов, А. Киров и Ар. (Sveshtnikov, 2001), (Barth, 2005), (Barth, 1960), (Men, n.d.), (Solovyev, 1884), (Kirov, 2001), като използваме метола на систематичното богословие, библейската херменевтика, екзегетика, както и познания от християнската етика, и старогрьцкия език. Практическият аспект на изследването се основава 
върху Ауховния опит на Авраам, историческия опит на Цьрквата, както и Аичния опит на автора.

Анализьт е основан на библейското определение за вяра в Посланието на апостол Павел към Евреите (11гл.) и примера за осъществяването й в живота и личността на Авраам (Стар завет). Авраам е избран порали схолството в Божието водителство към него и към новозаветните християни - негови наслеАници по вяра. Целта е тези наслеАници, жители на глобалната Мрежа $А$ б бьлат мотивирани $А а$ израстват в своята вяра, Аа преололяват изпитанията в живота, изпитания които спореА обещанието на Бога на библията никога няма $А$ а наАвишат силата им. Повлияни от потребителската култура на 21 в., съвременните християни бързо желаят да станат "Ауховни" чрез т.нар. "лела на вяра". Вярата сама по себе си не е гаранция, че човек ще получи непременно и веднага това, за което се моли (Евр. 11:39). Често искрената ревност и желанието за посвещение во следване на описаните в Библията герои на вярата с цел бързо постигане на техните резултати. Такава цел сама по себе си е добра, но не и когато се пропускат условията и реда за нейното постигане, поставени от самия Бог. Със Своя въпрос: "Когато АойАе Човешкият Син, ще намери ^и вяра на земята?" (Аука 18:8), Христос предрича пророчески това негативно развитие на новозаветната вяра от христоцентрична към спекулативна, "търсеща полза". Когато новозаветният вярващ получи вяра за спасение, той трябва $А$ я развива, Аа я проявява прави^но в живота си като благословено свилетелство за поколения напреА.

За вярата и морала. Като социално и нравствено същество човек изгражла своето отношение към околните съобразно нравствените критерии и културата на своята среда и епоха. Гръцката античност (най-вече П^атон) поставя в основата на нравственото отношение на човека към околните четири главни Аобродетели благоразумие, мъжество, въздьржание, справеАливост. Средновековието - в мицето на светите отци на цьрквата Климент А^ександрийски, блажени Йероним и блажени Августин - Аобавя Аруги три определящи добродетели: вяра, належла и ^юбов. Те се наричат 
"богословски", тъй като в християнски контекст (Тома Аквински) изразяват отношението на човека към Бога. Аюбовта е най-важната от тях, но тя нареА С належлата е основана на вярата.

Вярата е в основата на познавателния процес при човека, на неговата мисьл, Аействия и взаимоотношения. "Аа вярваме в Бога казва Соловьов в своето етическо съчинение - е наше нравствено зальлжение (Solovyev, 1920: р. 22). Нравственият аспект на вярата обаче не изчерпва нейната същност и цел. СреА тралиционните християни, които вярват по принцип, че Бог сьществува, има тьрсещи хора. Мнозина от тях се стремят Аа променят начина си за живот, опитват се Аа отстранят нравствените си грешки, но това или няма резултат, или успехьт е временен. Грехът не може $\Delta а$ бъде премахнат освен чрез Божията сила, ето защо никакви човешки старания не са способни $А$ а извършат това, което прави вярата. Тук е и основната разлика межАу християнството, Изтока и исляма. Нравствената ситуация не може $а$ бъле променена чрез нравствени усилия на човека и добър морал. Мнозина искат $\Delta$ а се приближат към Бога, но отХвърлят библейския пьт кьм Него - пьтя на истинско покаяние и приемане на Христос като ^ичен Спасител, и затова блужлаят, "всеки в своя пьт" (Ис. 53:6).

Библейският път към Бога и истинската вяра е покаянието. То е волеви акт, и за него е необхолима вяра. Няма покаяние без вяра, а вярата без покаяние не спасява. Истинското покаяние е човешки избор, възможен само чрез Божията благодат, която $А$ ава откровение на човека и му помага през целия християнски живот. Сьвременната "вяра" не търси същността, тя "сърорира", не се гмурка, като действа на принципа: "Вярвам в собствената си вяра." Огромната нужда от връщане към пьрвоизточника и автентичния образец на вярата, Sola Scriptura, провокира автора, да систематизира натрупаните (по)знания в тази област, като изхожАа от същността на християнското богословие: обективното Божие саморазкриване в Иисус Христос, възможно елинствено чрез вяра и по благолат. Богословието опрелеля вярата като своболен отклик на човека спрямо божественото откровение. Ако при разбирането за вярата се набляга най-вече върху умозаключенията, усещанията и преживяванията на човека, което е особено характерно 
за съвременното ^иберално богословие, не се взема предвил найважната предпоставка, а именно посветеният живот, "чисто сьрце, отворени кьм Бога очи, детско послушание, живот в Ауха и постоянно изучаване на Божието Слово" (Barth, 1960). Подобно на К. Барт и ние се противопоставяме на омаловажаването на Библията като Божие Слово, еАинствен авторитет и основа на християнското богословие.

3а вярата и науката. Като разсъжАава вьрху критериите за

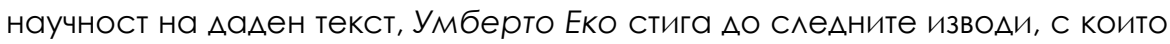
можем $\Delta а$ се съгласим:

"Изследването трябва да се отнася за обект, който е познаваем и мефриниран така, че $\Delta а$ бъле познаваем и за Аругите... $\Delta а$ Аеоринираме обекта, означава $\Delta а$ меоринираме условията, при които можем $\Delta а$ говорим за него, базирайки се върху правила, които ние ще опреАелим или които някой преАи нас е съставил... Изследването трябва да каже това, което още не е казано относно неговия обект, или Аа поглеАне от Аруг ъґА това, което вече е казано... трябва да бъле полезно за Аругите...Аа посочи основните материали за проверка на тезата, която защитава, както и да осигури материалите, за Аа могат и Аругите Аа продьлжат изслеАването." (Еkо, 1999: рр. 45-49).

Настоящото изследване на новозаветната вяра изхожАа от цитираните изисквания на У. Еко за научност, като при това основен извор на всички посочени и развити илеи е Библията. Писаното Божие Слово се разглежла като "текстова основа на разкрития обект на вярата" (Grentz \& Oslon, n.d.: p. 67). Освен това, кьм принципа Sola Scriptura ce Аобавя още еАин, зальлжителен за всяко богословско изследване и определен от Анселм Кентьрбърийски като Fides quarens intellectum ("Вяра, тьрсеща разбиране").

Вярата има Аве различни измерения: емпирично (експериментално) и духовно. Науката обаче не разглежла като свой обект пол каквато и Аа било формулировка понятия като Аух и абсолют,

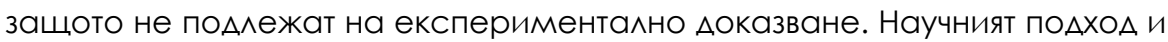
инструментариум са неприложими при търсенето на християнската 


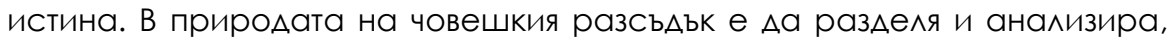

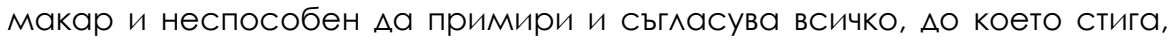
Аокато в природата на вярата е Аа сьелинява, примирява и сьгласува. Християнската вяра е отношение межлу субект и обект - нещо, което и науката приема безусловно като основна характеристика на вярата. Спореа богословието обектьт е Божият Син, Който не се нужАае и не полАежи на промяна - Той е образецьт, кьм който се стреми субектьт, т.е. човекът. Субектьт е този, който се нужАае от промяна и поллежи на промяна. За науката обаче субектьт и обектьт са равностойни в това отношение - те се изменят и развиват. Науката може $а$ a $\Delta$ але Аоказателства за съществуването на Бога въз основа на фактите от природата и историята, но тя не е в състояние чрез логическия си апарат, наблюденията и експериментите, които използва, $\Delta а$ предизвика у човека убежление, че Бог съществува. Религиозната вяра не е улостоверяване или предположение, а пьлно убежление в истинността на това, което е далено на човека. Александьр Мен пише, че вярата идва от чуване и следователно е основана на вьтрешен, Ауховен опит, който е коренно различен от научния експеримент. ЕАинственият пьт Аа се заловоли потребността на човека от пряко съприкосновение с божествената реалност е откровението от Бога, а то не може $а$ а се манипулира. Мен посочва като пример случая описан в Новия завет сьс самарянката, която в началото чува, слеА това разгласява чутото и в отговор на това сънародниците й казват:

"Ние вече вярваме не зарали това, което ти ни каза, понеже сами чухме и знаем, че Той е наистина Спасителят на света." "Това е научен подход, науката не може да напреАва без опит. В Ааления случай опитьт играе голяма роля, но това е вътрешен, Ауховен опит. Това е реалност, с която човек трябва $\Delta а$ се срещне. Ако той иска $\Delta а$

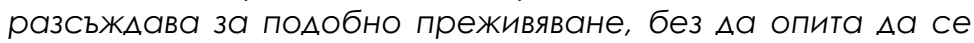
срещне с тази реалност и $\Delta$ а се $А$ окосне $\Delta о$ нея, тя ще му се изпльзне. Можеш Аа виАиш Христос само със сърцето си. Научно (чисто, така $\Delta а$ се каже, по външен пьт) можеш Аа разбереш Аруги неща: че Той Аействително е съществувал, каква е била Неговата срела и т.н. Това са важни въпроси, но те са вторични за вярата." (Men, n.d.: p. 7) 
Истината, разбирана като духовна реалност, не като фрилософрска категория, не може $\Delta а$ бъле открита вследствие само на човешко преживяване или разсъжление, а в резултат от послушанието на човешкия разум и по Божие откровение. В Своето откровение Бог сам "проговаря" на човека и го кани да влезе в трайни взаимоотношения с Него: взаимоотношения на пьлно приемане и пьлно отАаване.

Ако трябва $а$ а използваме научна терминология, Иисус може $а$ а бъле разгледан като "илеалния молел", който Бог е $А$ ал на човечеството: съвьршен образ, чрез който можем $\Delta а$ познаем Бога, и образец на пьлноценно общуване с Него. Този модел не поллежи на усъвьршенстване, а само на полражание. Човек не може да вили Христос по пътя на експеримента, т.е. с външни научни средства, а само със своето сърце. Това е прави^ният и еАинственият път за взаимоотношения с Бога.

"Вярата се проявява като вътрешна, непосредствена увереност в наличието на нещо, което Аушата тьрси, което я привлича и без приближаването и усвояването на което тя изпитва мьката на мишението, на непьлнотата на живота. Това е жажАа за близост, за съзАаване на условия за израз и изказ на насъбрани в Аушата чувства, мисли и пориви, свързани с обекта на тьрсенето, на жаждата." (Poshev, 1976: p. 8)

При такова търсене на човешката душа обектьт на вярата може Аa бъле само Бог. Богът на Библията е Аичност и затова има мични нравствени взаимоотношения с хората. Човек започва да вярва в Бога, когато открива в Него източник на живот и си^а, вижАа Го като Аюбящ баща. Като развива своята вяра субектьт се променя, а това е процесът на освещение и съ-разпятие.

Аефиниция. Библейски основаната вяра поставя в центьра Аичността и мисията на Богочовека Иисус. Ако евангелското учение се отлели от нея, то би се превърнало в религиозно-нравствена система без спасителна сила. Новозаветната вяра не е светоглеА, тя променя светогледа, и е пьлно доверяване на Божия авторитет, сърцевината на 
вътрешния живот у човека. Всичко друго е слелствие. В съвременното християнство често се обърква правилната послеАователност. Второстепенното става основно, търсят се видимите неща, които и Сатана има власт $\Delta а$ Аале (^ъжеучители, антихристи, ^ъжепророци, измамни знамения). Когато човек се ограничава само в земното, вилимото измерение на вярата, той я разбира като изпьлнение на собствените си очаквания: "Аа видя и да получа". Това е спекулативна вяра, която търси ползата и в която виАимото е центьр. Оттук произлиза еАно от съвременните ^ъжеучения в християнството "благовестието за просперитета", което не само мишава вярата от невидимото й измерение, но и я осакатява. Човекът с такава вяра е уловлетворен, ако получава виАимото тук, на земята. Причината за подобно отстьпление от зАравата вяра е в изместването на центьра и възприемането на вярата като реална САМО ПРИ УСАОВИЕ, че е виАима и осъществена Анес и сега. Ао такава вяра са стигнали вярващите от Коринт. По тази причина ап. Паве^ им пише: "И ако само през този живот се наляваме на Христа, ние сме най-окаяни от всички човеци" (I Кор. 15:19).

За $А$ изясним разграничаването межАу истинска и спекулативна вяра (фриг. 1) ще разгледаме определението за вярата от Послание към евреите: "А вяра е жива представа на онова, за което се наляваме, и разкриване на онова, що се не вижАа" (11:1, СИ). В най-използваните български преводи има някои различия. На пьрво място:

○ "жива представа на онова" (Синодално изАание)

- "Ааване същественост на ония неща" (Ревизирано изА., 1924)

- "твьраа увереност в неща" (РИВ).

Ето и Аруга важна разлика:

- "разкриване на онова" (Синодално издание)

- "имаме убежление за неща" (Ревизирано изА., 1924)

- "убеленост в неща" (РИВ). 


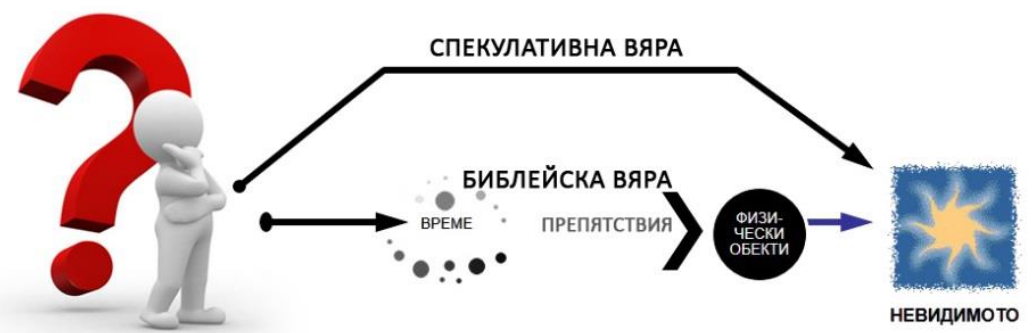

Фиг. 1. Истинска и спекулативна вяра

Нека се обърнем и към старогръцкия

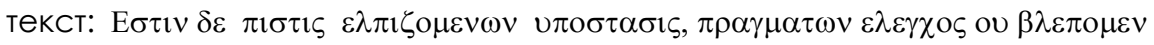

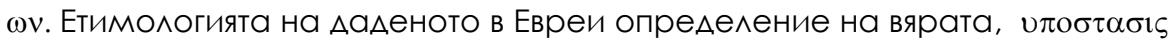
(увереност), Аава няколко значения: същност, Аействителност, основа, увереност, належла, гаранция, вкл. удостоверяване в Аокументи, свидетелстващи за притежание (Kleon, 2001: р. 828). В папирусите Аумата влєүхо означава Аоказателство в съАа, което полкрепя обвинението. Като използваме този превод на отАелните Ауми, ще преАложим слеАното опреАеление за вярата: вярата е Аействителност на нещата, които очакваме, увереност в Аела, които не се вижАат. Според това тьлкуване вярата не е осьществяване на човешко желание, а твъраа увереност в невидимото от еАна страна, в неща, които могат Аа станат виАими скоро или слеА време спореА Божията воля, но, от Аруга страна е и увереност в неща, които могат Аа се осьществят само във вечността. СлеАователно вярата Аейства в Ауховният свят и в материалния (вж. фриг. 2), като се развива еАновременно в няколко

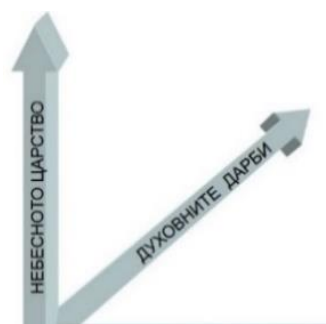

МАТЕРИАЛНИЯТ СВЯТ насоки: (1) Вяра в пьрвоначално невиАими неща, които чрез нея стават виАими, (2) Вяра в Ауховни и невидими неща, които получаваме, преживяваме и прилагаме в живота (Аарби на Ауха), (3) Вяра в неща, които вярваме, че ще получим, и получаваме, но във вечността.

Фиг. 2. Аействие на вярата в три посоки и Аве измерения: Ауховно и материално 
Живот по пАът и живот по дух. Изначалната Авуизмерност на вярата обуславя разграничението межАу "Аела на пльтта" и "п^одове на Ауха", както и "Живот по п^ьт" и "живот по Аух". Историята на Цьрквата е богата с герои на вярата, чиято вяра е била благословение за редица народи. Те, както и Авраам, са полагали много труд и усилия, за да постьпват не по п^ьт, а по дух. Вярата в спасението, в съразпятието, жертвена вяра и вяра, която въвежАа в Божията слава са части от Аьлгия процес на живота по Аух (фриг. 3). ЗАравата вяра не е статична, тя се развива, при това стьпаловиАно. Това е показано схематично като стьлба, за която ползваме библейския модел на стьлбата-вяра от видението на Яков и описваме Аетайлно в следващите страници.

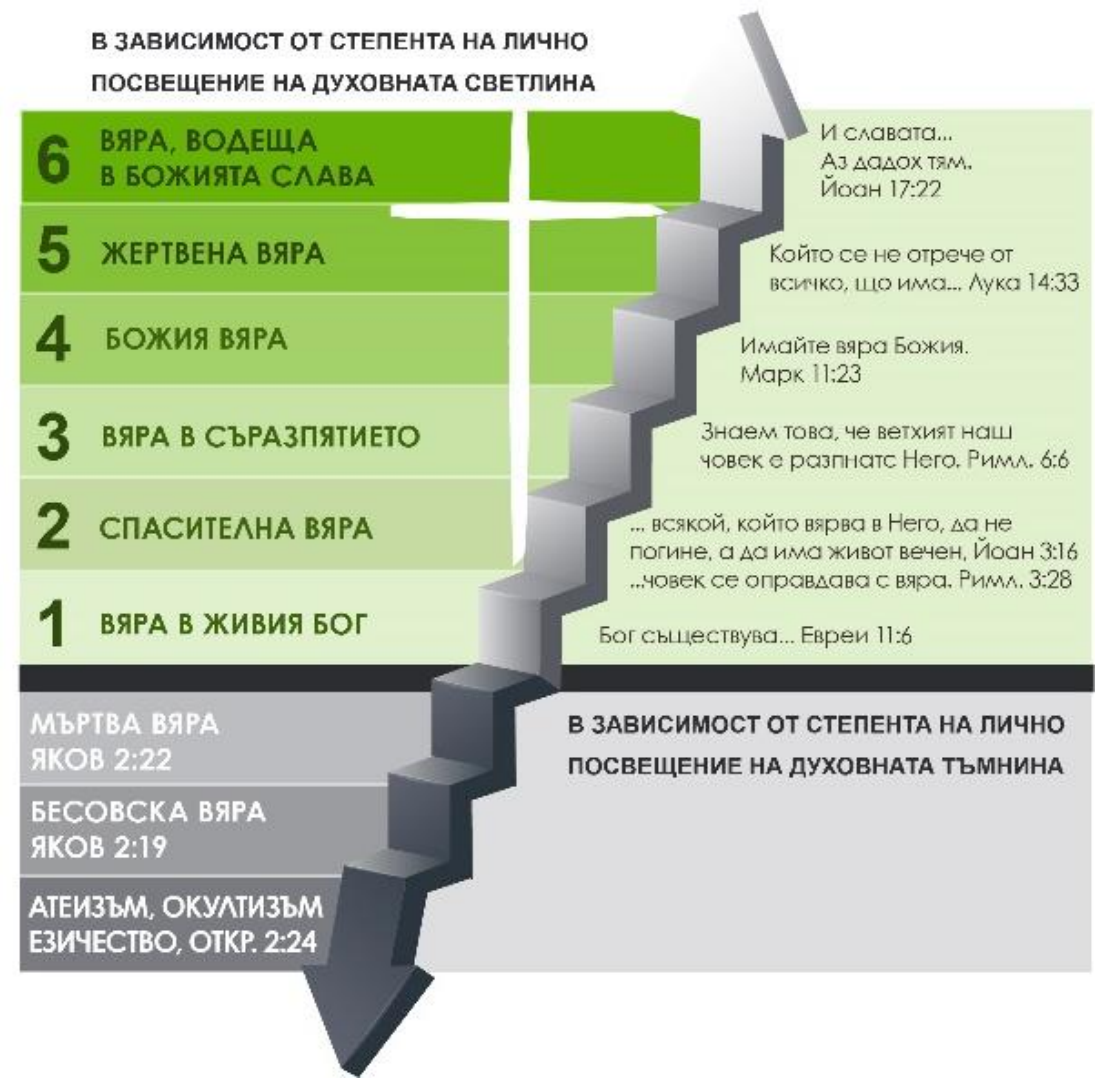

Фиг. 3. От вяра към вяра (авторска схема) 
Тази стьлба, съединяваща земята и небето, е образ на Ауховната стьлба, по която старозаветните патриарси Авраам, Исаак и Яков (Евр. 11:9) чрез живот на вяра и послушание се изкачват към небесната слава, но това е и пьтят на всички, които Бог призовава $а$ се

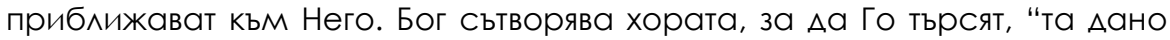
някак биха Го попипали и намерили, макар че Той не е $А$ неч от всеки еАин от нас; защото в Него живеем, Авижим се и съществуваме" (АА 17:27-28). Кръстьт присьства в схемата като онова, което Авраам наймного иска Аа виАи - изпьлненото Божие обещание.

Мъртвата вяра е пол основата на тази стьлба. Атеизмът е също вяра, но "вяра в нулата“, както пише Аостоевски. Окултизмът от своя страна е определяна в Библията като „вяра на бесовете“, която воли човека кьм Ауховна тьмнина и мрак. Вярата трябва $а$ а бъле разумна, т.е. обоснована, а не сляпа или суеверна. Аъжливите понятия и убежления за врьзката межАу нещата и за отношенията межАу сетивния материален и свръхсетивния духовен свят (мистика и религиозен окултизьм) пречат за усъвьршенстването на човешкото съществуване, изопачават характера на християнството, нарушават нравствеността, во $я$ т $А$ фоанатизъм и езичество, Аоказано и в историята на Цьрквата.

Шестте стьпала на вярата, нал $и$ иията от фриг. 3 , се полрежлат както слеАва:

1. Първото стъпало е "вяра в истинния Бог”, вярата, че Бог съществува: "Който илва при Бога, трябва $а$ ва вява, че има Бог и че възнаграждава тези, които Го тьрсят" (Евр. $11: 6)$. Освен християните в живия Бог вярват и евреите, но те признават Иисус Христос просто като учител, затова са на еАно стьпало с фрормалните християни. За хората на това стьпало Иисус казва: "Не си далеч от Божието царство" (Марк 12:34). Христос казва още: Понеже ето, царството

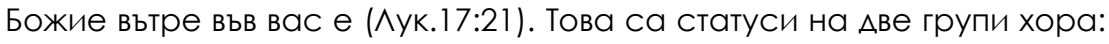
елните близо $А$ Царството, Аругите са в него. Фактьт, че човек признава съществуването на Бога, не означава, че той е в Царството Божие. Аобрите дела, самоправелността го отлалечават от него. Естествената вяра за съществуването на Бога е само началото. ЕАва слеА мичната си среща с Бога, вярата на Авраам качествено се

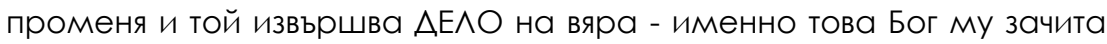


за прав $а$. Не просто вярва в Бога, а на Бога, в Неговото Слово и обещания.

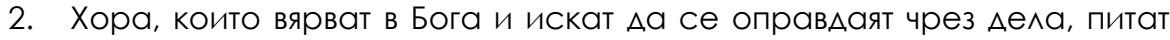

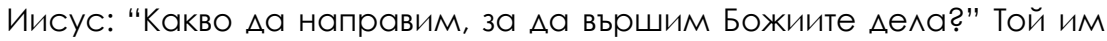

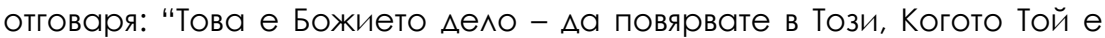
изпратил" (Йоан 6:28-29). Христоцентричността на новозаветната вяра се откроява и в разговора на Иисус с Николим: "Който вярва в Него, не е осъден; който не вярва, е вече осьден, защото не е повярвал в Името на ЕАинородния Божи Син"(Йоан 3:18). Безусловното приемане на Христос е второто Аело на спасяващата вяра, което слага край на мьртвата вяра и мьртвите дела и поставя начало на живата вяра и духовните дела. Човек прилобива вяра в своето мично спасение не чрез заслуги, а по благодат и посреАством мично откровение от Отец. Когато приема с вяра Христос като мичен Спасител, на второто стьпало, Бог възнаграждава човека с качествено друга вяра, вяра в спасението Му. „А на всички ония, които Го приеха, - на вярващите в Неговото име, - $а$ але възможност $а$ а станат чеда Божии; те не от крьв, ни от похот п^ьтска, нито от похот мьжка, а от Бога се родиха". (Иоан.1:1213). Важно уточнение е, че вяра в спасението човек придобива само чрез Божието откровение. Сам човек никога не би могьл $\Delta а$ се изкачи на тази височина, това е качествена разлика с учението за кармата и като ця^о С всички източни фри^ософиии и религии, които прокрамират сьстояние на нирвана и сливане с безличната сврьхенергия. Когато Христос пита учениците Си според хората кой е Той, Петьр отговаря: "Ти си Христос, Синьт на живия Бог." А Иисус му казва: "Блажен си, Симоне, сине Йонов, защото пльт и крьв не са ти открили това, а Моят Отец, Който е на небесата"(Мат. 16:16-17). Бог възнаграждава търсещите и намерилите Го с обогатяване и трансорормиране на естествената вяра с дарба вяра. Тази дарба Аава ^ичната убеленост, че човека е простен, приет и осиновен от Него. Това не е внушение или самовнушение, а духовно прозрение. Тук е началото на израстването във вярата, която на това стьпало преминава от интелектуално-нравствено в Ауховно измерение. Тази вяра има Ауховно-възражлаща, нравствено-преобразуваща сила, 
защото е дар от Бога за тези, които Го търсят. Самият Бог възпитава вярата в човешкия рол със Своите обещания, откровения, ми^ост, благодеяния, присъди и наказания. Този, който е уверен, че името му е записано в Книгата на живота, не може $а$ б бъле разколебан. Мойсей знае, че името му е записано там, когато се моли: „заличи мен от книгата, която си написа^!" (Изх. 32:32).

3. Третото стъпало, вяра в съразпятието, е за тези, които не спират развитието си на ниво "простени и оправдани", а тръгват по тесния пьт на освещението и послушанието. Бог не принужАава човека $\Delta а$ тръгне по пьтя на послушанието, това би било в противоречие с Божието нравствено съвьршенство. Аврам трябва да прояви послушание доброволно и $и$ а трьгне за Обещаната земя. Послушанието е плод на вярата, която ни свързва с Бога и $А$ ава възможност за живо общение с Него. "С вяра Авраам послуша, когато бе повикан Аа излезе и да отиде на еАно място, което щеше Аа получи в наследство, и излезе, без да знае кьле отива" (Евр. $11: 8$ ) т.е. "ходи с вярване, а не с виждане" (II Кор. 5:7). Така е и с новозаветния вярващ - преАи новоражАането си той е имал Аобри дела и някаква вяра, но и двете са нелостатьчни за спасението му. Сьразпятието приковава старата греховна прирола на човека на кръста, за да придобие човек истинска свобода от своето Аз в суетата на ежелневието. Важно е $а$ с се отбележи, че съразпятието не означава просто израстване в нравствеността. Това е трудният процес на освещение и приближаване $А$ сърцето на Бога, описана от протойерей П. Солярски по този начин: "ГАавното предимство на човешката душа се състои в това, че тя е съзАалена по Божия образ, изкупена е от Христос и е призована към безкрайно усъвьршенстване $\Delta о$ уполобяването й на Христос. Грижата за нея основно трябва $\Delta$ а се сьстои в това постоянно $\Delta$ а се разкриват Ауховните й сили, постоянно Аа се съживяват и обновяват в нея богоподобните черти." (Solyarsky, 1884: р. 228). Освещението е процес, който не предполага, че човека познал Бога, няма повече да греши. Факт е, че всички ние често сьгрешаваме: "Ако кажем, че не сме съгрешили, правим Бога ^ъжец и Неговото Слово не е в нас" (І Йоан 1:10). Непослушанието на Аврам потвържАава това, той 
отива в Египет порали глала, забрави^ с Кого трябва $А$ с се посьветва (Бит. 12:9-10) и решава въз основа на своя опит. Голяма грешка е човек $\Delta а$ не се опира на Божието обещание, а на своята ^огика. За Аврам Египет се оказва к^опка, к^опката на неговия опит (Бит. 12:1719). След като обаче вижда Божията намеса, той си трьгва от Египет засрамен."И от южната страна той се приАвижи постепенно $А$ о Ветил, Ао мястото, къАето... първоначално беше изАигнал жертвеник. И там Аврам призова Господното име " (Бит. 13:3-4). Това е процесьт на освещение и промяна и за новозаветния християнин.

4. Четвьртото стьпало, Божия вяра, е за позналите силата на съразпятието и истинската свобода: живот по Аух. Само те могат $А а$ бъАат използвани като сьАове за почтена употреба от Бога, Който чрез Светия Аух ги Аарява с дарбата вяра. В книгата си "Трите аспекта на етиката" профр. А. Киров пише: "Аухьт (пнеума) е вьтрешният, същинският човек, който често противостои на ск^онностите на телесния... Аухьт е извор на сврьхестествен живот... Той също е Аух на вярата (II Kор. 4:13)." (Kirov, 2001: p. 57).

5. Петото стьпало, жертвена вяра, очаква тези, които, слеА като са приАобили опит във взаимоотношенията си С Бога, са готови $А$ व положат на олтара всичко, придобито от Него и чрез Него. Жертвената вяра воли Авраам кьм хьлма Мория. Обстоятелствата, които Бог Аопуска в живота на Авраампреди и слеА Мория, променят коренно неговата вяра и взаимоотношенията му с Бога. Крайният резултат е пьлното Аоверие и взаимно приятелство межАу Бога и Авраам: “...и беше наречен Божи приятел” (Як.2:23) (Kidner, 2001: p. 151).

6. На Шестото стьпало, вяра, която въвежАа в Божията слава, БоГ споделя Своята слава с истинските Си ученици, преминали през петте преАходни стьпки. Авраам приАобива вечна слава от Бог Отец само слеА като отаава своя син на жертвеника с вяра в Неговите обещания. Според същия Ауховен принцип Христос сполеля Своята слава с новозаветните християни, посветили себе си на Него. Селмото стьпало е фринальт по стьлбата, то въвежла в небето, там пребълва само Аюбовта и няма Аа има нужАа от вяра. 
Ако резюмираме характеристиките на богоугонната вяра, които са нужни за изкачването по стьлбата, те са следните: пьрво тя е разумна, т.е. обоснована, а не сляпа и суеверна: "Бьлете винаги готови $а$ а отговаряте (но с кротост и страхопочитание) на всеки, който ви пита за вашата належла" (І Петр. 3:15); вярата не е статична, тя сленва да се развива, като опознава от опит своя обект: "Но растете в благодатта и познанието на нашия Господ" (II Петр. 3:18). Когато християнинът се стреми Аа изпьлнява Божията воля, като изучава послеАователно И в контекст книгите на Библията, и ги прилага в ежеАневието си, той намира за себе си нови обещания, опознава и израства в Бога; вярата трябва да е твърда и здрава: "...Аа бъдат зАрави във вярата" (Тит 1:13), постоянна, а не колеблива: "Стойте твърАО във вярата! Бъдете мъжествени; укрепявайте се!" (І Кор. 16:13). Понякога покаяли се хора не постоянстват в молитва, техните сьрца не стават жертвеници, кьлето $А а$ гори Аюбов към Бога, към ближния, и вярата ^есно се преврьща в навик на енна безплодна религия. Сам Христос описва полобна вяра и нейните носители като „варосани гробници“. Тогава светилника на сьрцето слелва да бъле поправен, за да свети отново.

\section{Вместо заключение... богоугонна вяра Анес?}

Християнството учи, че греховната природа придобиваме по наследство, както и по наследство човек е лишен от ^ично общение с Бога, освен чрез гласа на съвестта, отвън. ЕАинственият пьт за връщане на това общение е личната вяра в извършеното от Христос спасително Аело на Крьста. Бог Аействително спасява тези, които Го тьрсят и призовават, но има условия за спасение и те са: осьзнаване на своята греховност, искрено покаяние и приемане на Неговата прошка, приемането на Христос като мичен Спасител. Вярата не е статично понятие, а Аинамична реалност за новозаветния християнин, когато е правилно деоинирана и библейски обоснована. Шест-степенната стьлба на вярата показва това развитие по елин Ауховен и практичен начин. Това е пьт, по който разумната вяра се променя същностно и преминава от интелектуално и нравствено в Ауховно ниво. Това е началото на израстването във вярата, към което всеки, който се нарича с името на Христос е призован. 


\section{МИTEPATYPA / REFERENCES}

Barth, K. (2005). Poslanie k rimlyanam (in Russian). Publisher: Bibleysko-bogoslovskii institute sv. ap. Andreya, Moscow, Russia, ISBN: 978-5-89647-351-0 // [Барт, К. Послание к римлянам. Москва, Библейско- богословский институт св. ап. АнАрея, 2005. ISBN: 978-5-89647-351-0].

Barth, K. (1960). Anselm: Fides Quarens Intellectum. London, 1960. ISBN 9780915138753.

Bible, (2006). Biblia, izdanie na Sv. Sinod na Balgarskata Tcarkva (in Bulgarian), Publisher: Balgarsko bibleysko druzhestvo, Sofia, Bulgaria, 2006, ISBN 13:978-9548968-32-4 // [Библия, изаание на СВ. Синол на Бьлгарската Цьрква, Софрия 2006,Българско библейско Аружество, 2006, ISBN 13: 78-954-8968-32-4].

Eko, Um. (1999). Kak se pishe diplomna rabota (in Bulgarian), Sofia, Bulgaria, 1999, pр. 45-49, ISBN: 9789543983230 // [Еко, У. Как се пише Аип^омна работа. С., 1999, c. 45-49. ISBN, 9789543983230$].$

Grentz, J.; Oslon, R. (n. d.). Who Needs Theology?: An Invitation to the Study of God. ISBN 0851111777.

Kidner, D. (2001). Star zavet. Bitie (in Bulgarian), Sofia, Bulgaria, 2001, ISBN9549069214 // [Киднер, А. Стар Завет. Битие. С., 2001. ISBN9549069214].

Kirov, D. (2001). Trite aspekta na etiketa. P. 1 Antropologia (in Bulgarian), ISBN 9547740016 // [Киров, А. Трите аспекта на етиката. Ч. 1. Антропология. С., Университетско изАателство, 2001. ISBN 9547740016].

Kleon, L. (2001). Noviy lingvisticheskii i ekzegeticheskii klyuch k grecheskomu tekstu Novogo zaweta (in Russian), Sankt Petersburg, Russia, 2001, ISBN 9785745410468 // [К^еон, ^. Новый Аингвистический и экзегетический кАюч к греческому тексту Нового завета. Санкт-Петербург, 2001, ISBN 9785745410468].

Men, Al. (n. d.). Bit hristianinom (in Russian), ISBN 978-0-00-918786-0 // [Мень, А^., Быть христианином. с. 7. ISBN 978-0-00-918786-0].

Poshev, G. (1976). Osnovni nachala na hristianskoto semeystvo (in Bulgarian), Publisher: Duhovna kultura, 1976, ISSN 0324-1173 // [Пошев, Г., Основни начала на християнското семейство. - Ауховна култура, 1976, № 5. ISSN 0324-1173].

Sveshtnikov, VI. (2001). Ocherki hristianskoi etiki. Polomnik (in Russian), 2001, ISBN 9785-91173-210-3 // [Свещников, В^. Очерки христианской этики. Поломникъ, 2001. ISBN 978-5-91173-210-3].

Solovyev, VI. (1920). Duhovnie osnovi zhizni (in Russian), Moscow, Russia, ISBN: 978-54475-5101-8 // [1920 Соловьев, Вл. Ауховные основы жизни. Москва, 1920. ISBN: 978-5-4475-5101-8].

Solyarsky, P. (1884). Nravstvenoe pravoslavnoe bogoslovie (in Russian), Sank Petersburg, Russia, 1884, ISBN 2007000049 // [Солярски, П. Нравственное православное богословие. Санкт-Петербург, 1884, т.3. ISBN 2007000049].

Valkov, Iv. (2008). Bozhiat izbor za spasenie chrez vyara i lyubov (in Bulgarian), Publisher: Svetlina na balkanite, Sofia, Bulgaria, ISBN978-954-91394-2-6 // [Вълков, И. Божият избор за спасение чрез вяра и любов. ИзА. Светлина на Балканите, С., 2008. ISBN978-954-91394-2-6]. 


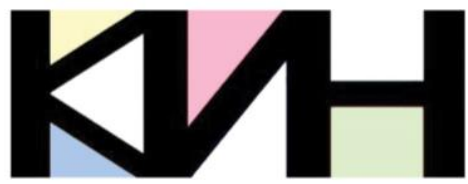

КУАТУРНО-ИСТОРИЧЕСКО НАСАЕАСТВО:

ОПАЗВАНЕ, ПРЕАСТАВЯНЕ, АИГИТААИЗАЦИЯ

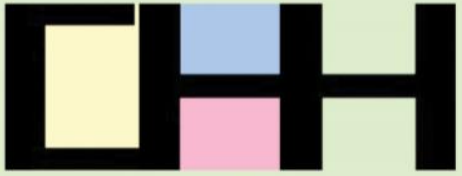

CULTURAL AND HISTORICAL HERITAGE: PRESERVATION, PRESENTATION, DIGITIZATION
Материалите в сборника са обект на авторско право. Разрешава се безвъзмезАното ползване на техни електронни/ хартиени копия само за лична употреба или обучение, при пь^но цитиране на текущата страница и слеА писмена декларация от цитиращия за мипса на търговски намерения.

(с) Авторски колектив, 2020

Техническо реАактори: Калина Сотирова-Вълкова Николай Ноев Паска^ Пиперков

\section{Editors}

Petko St. Petkov

Galina Bogdanova

This work is subject to copyright. Open and free of charge use of digital/hard copies of publications is granted only for personal or educational use, with full citation of the current page, and after written declaration of the quoting side for notcommercial Intention.

(C) Authors` Group, 2020

Technical editors:

Kalina Sotirova-Valkova

Nikolay Noev

Paskal Piperkov

НАЦИА регистрационен № 1209

Научна пореАица: том 6, брой 2 (9)/2020

Science series: vol. 6 , issue $2(9) / 2020$

NCID Registry No. 1209

www.math.bas.bg/vt/kin

ISSN: 2367-8038 